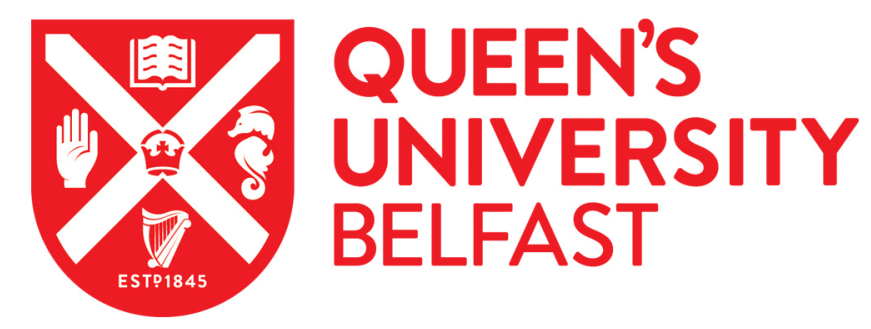

\title{
Chemoenzymatic Synthesis of (-)-Ribisins A and B from Dibenzo[b,d]furan
}

Boyd, D. R., Sharma, N. D., McGivern, C. J., Stevenson, P. J., Hoering, P., \& Allen, C. C. R. (2019).

Chemoenzymatic Synthesis of (-)-Ribisins A and B from Dibenzo[b,d]furan. Journal of Organic Chemistry, 84 , 15165- 15172. https://doi.org/10.1021/acs.joc.9b02171

Published in:

Journal of Organic Chemistry

Document Version:

Peer reviewed version

Queen's University Belfast - Research Portal:

Link to publication record in Queen's University Belfast Research Portal

Publisher rights

Copyright $\odot 2019$ American Chemical Society. This work is made available online in accordance with the publisher's policies. Please refer to any applicable terms of use of the publisher.

\section{General rights}

Copyright for the publications made accessible via the Queen's University Belfast Research Portal is retained by the author(s) and / or other copyright owners and it is a condition of accessing these publications that users recognise and abide by the legal requirements associated with these rights.

Take down policy

The Research Portal is Queen's institutional repository that provides access to Queen's research output. Every effort has been made to ensure that content in the Research Portal does not infringe any person's rights, or applicable UK laws. If you discover content in the Research Portal that you believe breaches copyright or violates any law, please contact openaccess@qub.ac.uk. 


\title{
Chemoenzymatic Synthesis of Ribisins A and B from Dibenzo[b, $d]$ furan
}

\author{
Derek R. Boyd, ${ }^{\dagger}{ }^{\dagger}$ Narain D. Sharma, ${ }^{\dagger}$ Christopher J. McGivern, ${ }^{\dagger}$ Paul J. Stevenson, ${ }^{* \dagger}$ Patrick Hoering ${ }^{\S}$ \\ and Christopher C. R. Allen ${ }^{\S}$
}

†School of Chemistry and Chemical Engineering, Queen’s University, Belfast, BT9 5AG, UK
${ }^{\S}$ School of Biological Sciences, Queen’s University, Belfast, BT9 7BL, UK

ABSTRACT: cis-Dihydrodiols, derived from monocyclic aromatic compounds, are valuable chiral pool intermediates for the synthesis of cyclic natural products. A drawback of this approach to the synthesis of polycyclic secondary metabolites, is that the additional rings must be annulated. To date, relatively few chiral natural products have been synthesized from polycyclic arene cis-dihydrodiols. Fungal metabolites ribisins A and B, have now be obtained by functional group manipulation of a major tricyclic arene metabolite, obtained from toluene dioxygenase-catalyzed regioselective and stereoselective $c i s$-dihydroxylation of dibenzo $[b, d]$ furan. The synthetic sequences were marginally shorter than the alternative routes using monocyclic arene cis-dihydrodiols and required

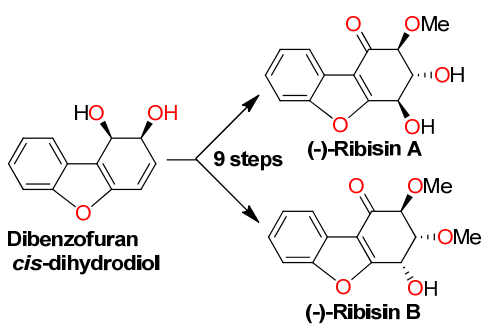
no carbon-carbon bond-forming reaction.

\section{INTRODUCTION}

The dibenzo[ $[b, d]$ furan (dibenzofuran) skeleton is present in a number of biologically interesting chiral natural products, including galanthamine, opiates (e.g. morphine), and the ribisins (Figure 1). Ribisins are a family of polyoxygenated dibenzofuran derivatives, which were isolated by Fukuyama and coworkers, from the fruiting bodies of the white rot fungus Phellinus ribis. ${ }^{1}$ This microbial species has a history of use in traditional medicines where it was used to enhance immunity, as well as to treat gastrointestinal cancer, liver or heart disease and diabetes. ${ }^{2-4}$ Ribisins A-D, in particular, enhance the ability of nerve growth factor to promote neurite outgrowth in PC12 cells and may have potential in the treatment of stroke, brain trauma and Alzheimer's disease. ${ }^{1}$

Two approaches to the synthesis of ribisins have, to date, been reported. ${ }^{5-7}$ The key step in Du's synthetic approach to ribisin A was to use a Ferrier rearrangement of an enol ether, derived from $\alpha$-D-glucopyranose, with all three stereocentres of the correct absolute configuration. ${ }^{5}$ Banwell's seminal syntheses were chemoenzymatic and used a chiral cis-dihydrodiol, derived from bromobenzene, as starting material. ${ }^{6,7}$ This approach not only gave additional material for further biological evaluation but also led to a correction of the published absolute stereochemistry for ribisin $\mathrm{C}$ and the relative stereochemistry for ribisin $\mathrm{B}$, where two out of the three stereocentres had to be reassigned. The structures of ribisins $B$ and $C$ shown in Figure 1 are thus the corrected versions determined by Banwell et al. ${ }^{6,7} \mathrm{~A}$ possible biosynthetic pathway to ribisins A-D from 2-hydroxycinnamic acid in P. ribis, via oxidoreductase-catalyzed reactions, was reported by Fukuyama et al. ${ }^{1}$

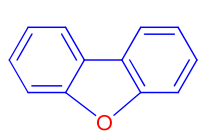

Dibenzofuran<smiles>C[C@H]1C(=O)c2c(oc3ccccc23)[C@H](O)[C@@H]1O</smiles>
Ribisin A

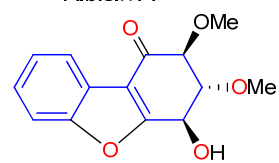

Ribisin C

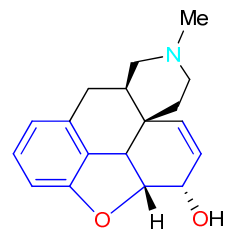

Galanthamine

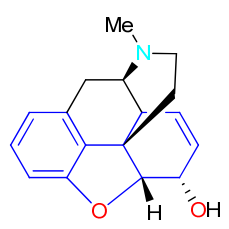

Morphine<smiles>CO[14C]1Oc2oc3ccccc3c2C(=O)[C@@H](O)[C@@H]1O</smiles>

Ribisin B

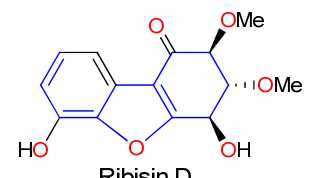

Ribisin D

Figure 1. Examples of natural products containing dibenzofuran subunits (Scheme 1).

This proposed route involved the formation of an intermediate dibenzofuran-1,3-(2H,4H)-dione tautomer of dibenzofuran1,3-diol, and enzyme-catalyzed oxidations to yield ribisins A and B. Monooxygenase-catalyzed epoxidation of benzoate esters to form arene oxides, oxepines and phenols, ${ }^{8}$ and laccasecatalyzed oxidation of phenols were reported using $P$. ribis cultures. ${ }^{9}$ The postulated biosynthetic sequence, through a dibenzofuran precursor (Scheme 1) prompted the current chemoenzymatic approach to ribisins A and B from dibenzofuran. 


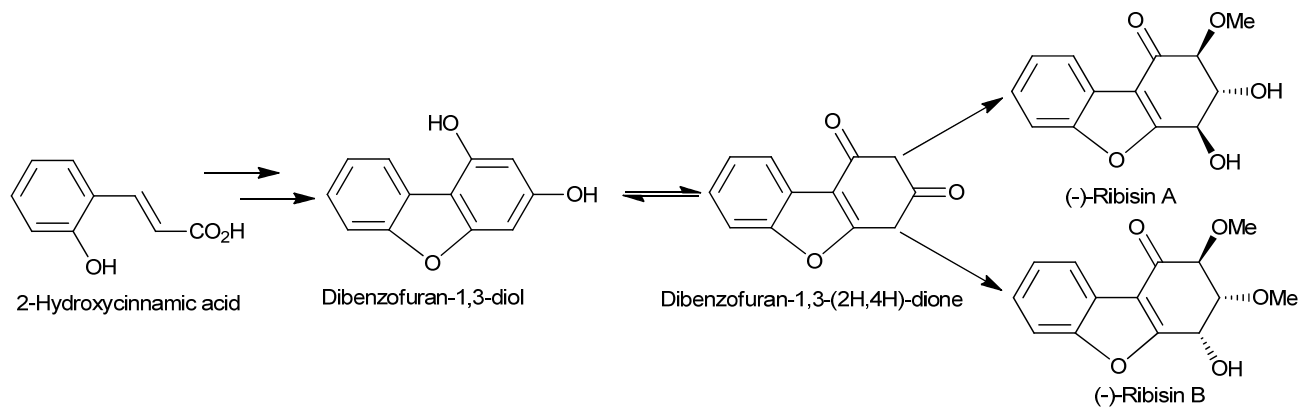

Scheme 1. Proposed biosynthetic route to ribisins A and B from 2-hydroxycinnamic acid and a dibenzofuran intermediate
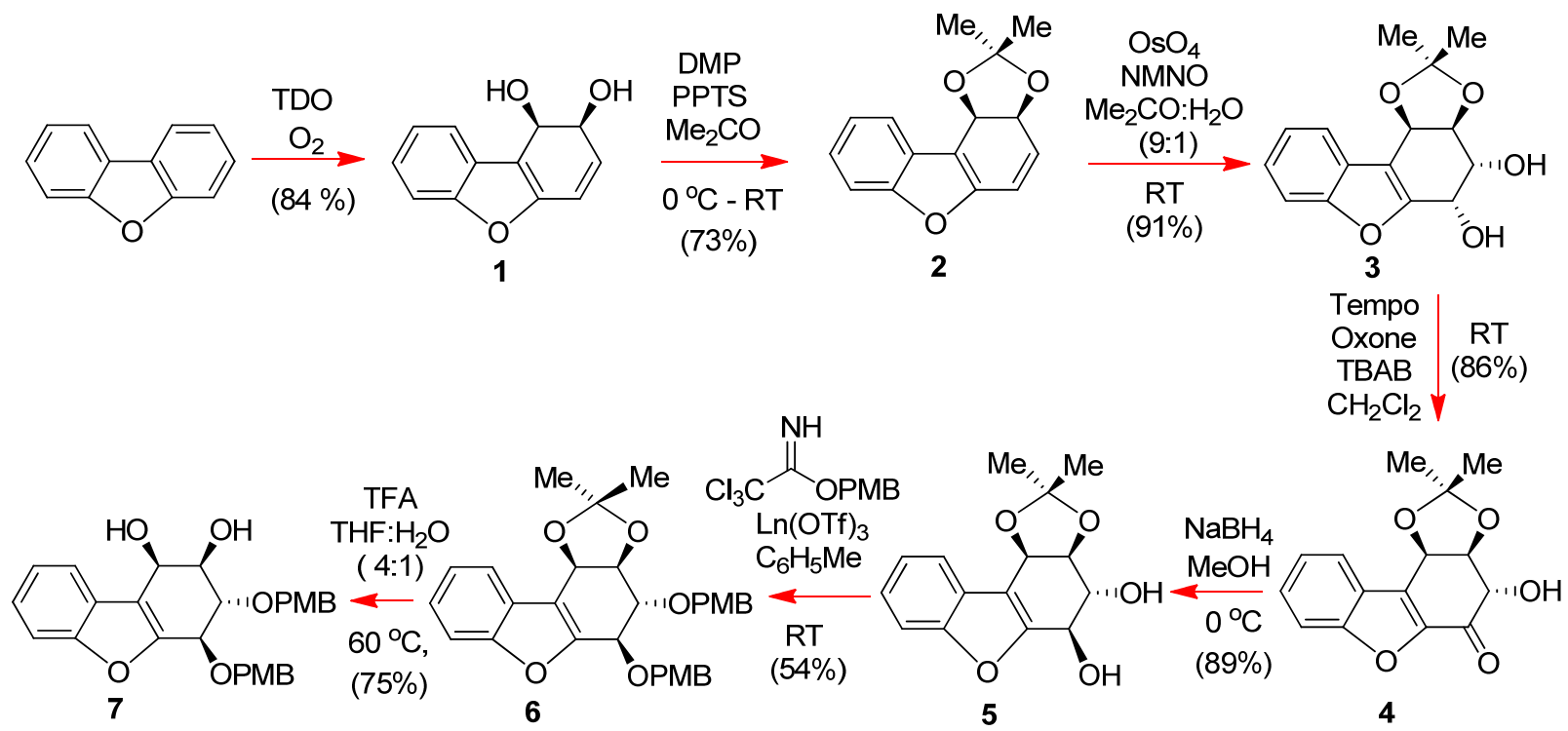

$$
\begin{array}{c|c}
\mathrm{RT} & \text { Tempo } \\
(55 \%) & \text { Oxone } \\
& \mathrm{TBAB} \\
\mathrm{CH}_{2} \mathrm{Cl}_{2}
\end{array}
$$

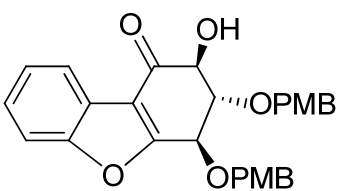

8
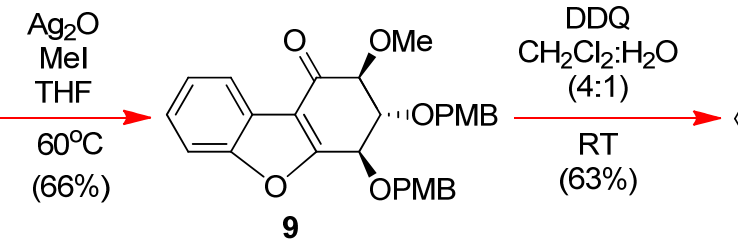<smiles>COC1C(=O)c2c(oc3ccccc23)[C@H](O)[C@@H]1O</smiles>

(-)-Ribisin A

Scheme 2. Synthesis of (-)-ribisin A 
<smiles>CC1(C)O[C@H]2c3oc4ccccc4c3[C@@H](O)[C@@H](O)[C@H]2O1</smiles>

3

$87 \%)$<smiles>COC(C)C(C)CCCC(C)(C)C(C)(C)Br</smiles><smiles>[R]C1([R])O[C@H]2c3oc4ccccc4c3[C@@H]3OC([Y4])(C)O[C@H]3[C@H]2O1</smiles>

10a $R^{1}=P M P, R^{2}=H$

$10 b R^{1}=H, R^{2}=P M P$

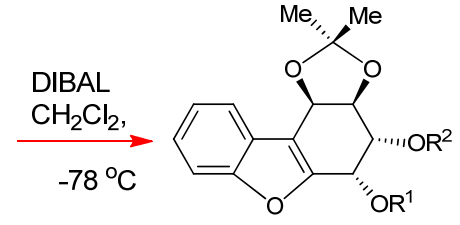

$11 \mathrm{R}^{1}=\mathrm{PMB}, \mathrm{R}^{2}=\mathrm{H}(30 \%)$

$12 R^{1}=H, R^{2}=P M B(16 \%)$

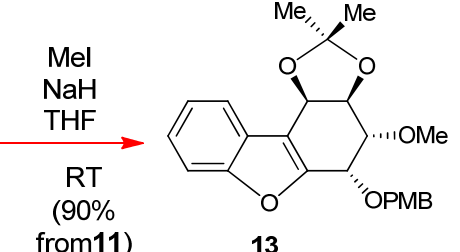

from11)

\section{3}

\begin{tabular}{l|l} 
TFA, & $50^{\circ} \mathrm{C}$
\end{tabular}

THF: $\mathrm{H}_{2} \mathrm{O},(97 \%)$

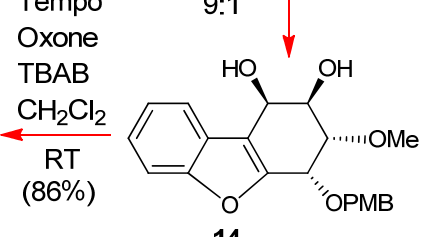

(-)-Ribisin B

DDQ<smiles>CO[C@@H]1[C@@H](OC)C(=O)c2c(oc3ccccc23)[C@@H]1O</smiles>

$\mathrm{CH}_{2} \mathrm{Cl}_{2}: \mathrm{H}_{2} \mathrm{O}$ (4:1)

$\mathrm{RT}$
$(77 \%)$

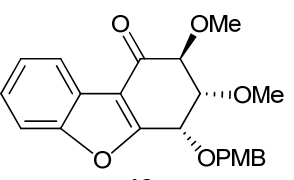

16

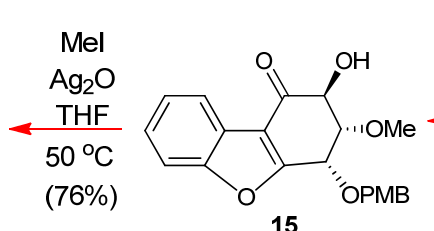

15

Scheme 3. Synthesis of ribisin B<smiles>OC1C=Cc2oc3ccccc3c2[C@H]1O</smiles><smiles>OC1[C@H](O)[C@H](Br)c2oc3ccccc3c2[C@H]1O</smiles>

17

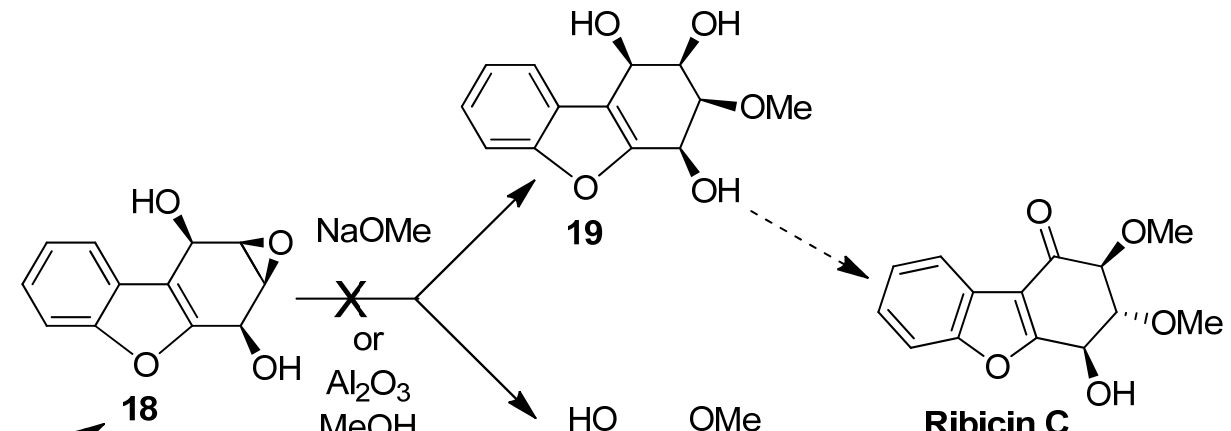

Ribicin C

\section{$\mathrm{NaOMe}$ \\ THF}

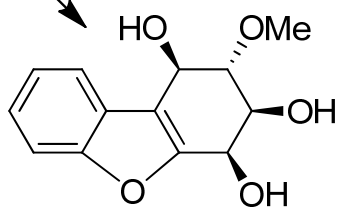

20

Scheme 4. Attempted synthesis of ribisin C

Biotransformations of monocyclic aromatic compounds are routinely utilized, to produce enantiopure cis-dihydrodiol metabolites for application in the chemoenzymatic synthesis of natural products. ${ }^{6,7,10-19}$ Conversely, cis-dihydrodiol metabolites, from polycyclic arenes or heteroarenes, are rarely used in chemoenzymatic synthesis. ${ }^{20}$ Thus, although the isolation and stereochemical assignment of cis-dihydrodiols from tricyclic aromatic substrates was reported, using naphthalene dioxygenase (NDO) $)^{21}$ or biphenyl dioxygenase (BPDO) ${ }^{20-23}$ as biocatalysts, few examples of their employment as chiral synthons have been documented. Furthermore, biotransformations of polycyclic arene substrates, with the latter dioxygenase types, often resulted in the formation of mixtures of cis-dihydrodiol isomers in relatively low yields. Biotransformations, using a mutant strain of the soil bacterium $P$. putida UV4 and E. coli recombinant strains, both expressing toluene dioxygenase (TDO), have been widely used in arene cis-dihydroxylations. In our laboratories, anilines, phenols, phenolic ethers, dibenzothi- ophene and dibenzofuran are among the more unexpected substrates recently found to undergo TDO-catalyzed cis-dihydroxylations. ${ }^{24-27}$

One possible chemoenzymatic approach to the synthesis of ribisins, was to start with dibenzofuran as substrate, and then to add the required four oxygen atoms to the metabolite in a stereocontrolled manner. This method had the advantage that no carbon-carbon bond-forming reactions occurred in the entire synthetic sequence and the number of steps in the synthesis could in principle, be reduced.

\section{RESULTS AND DISCUSSION}

Based on predictions, from molecular docking studies, and the use of $P$. putida UV4 whole cells (as TDO source), biotransformation of dibenzofuran resulted in cis-dihydroxylation at the pseudo-bay region leading to the isolation of metabolite 1 (84\% yield), with no evidence of other cis-dihydrodiol isomers being 
formed. ${ }^{27}$ cis-Diol 1, with dearomatization in one of the rings, was found to be enantiopure ( $>98 \% e e)$ and was ideally functionalized for conversion to ribisins $\mathrm{A}$ and $\mathrm{B}$.

Starting from dibenzofuran cis-dihydrodiol 1, a nine-step synthesis of ribisin A is outlined (Scheme 2). cis-Diol 1 was found to be acid-sensitive and readily dehydrated regioselectively, to give dibenzofuran-2-ol. Using the weak acid catalyst PPTS, cisdiol 1 was converted to acetonide 2 in (73\% yield) along with the dehydration product dibenzofuran-2-ol (11\% yield). During the TDO-catalyzed biotransformation of dibenzofuran, traces of a further cis-dihydrodiol metabolite, derived from cis-dihydroxylation of dibenzofuran-2-ol, was also detected. ${ }^{27}$

cis-Dihydroxylation of alkene 2, employing Upjohn osmylation conditions, ${ }^{28}$ proceeded as expected, exclusively, from the face anti to the bulky acetonide protecting group, to give the $c i$-diol acetonide diastereoisomer 3 (91\% yield). Due to steric inhibition of the acetonide group, attempted Mitsunobu inversion of configuration, at the C-4 chiral alcohol center of compound 3 was unsuccessful in our hands. The stereoinversion was achieved in two steps, by a chemoselective oxidation of the more activated alcohol of diol $\mathbf{3}$ to form $\alpha$-hydroxyketone $\mathbf{4}$, followed by a stereoselective reduction to give trans-diol $\mathbf{5}$. Although a number of methods were available, for the chemoselective oxidation of activated alcohols, a problem arose in this particular case; the oxidation product, $\alpha$-hydroxyketone 4 , was found to be very sensitive to further oxidation, leading to carbon-carbon bond cleavage. After screening oxidation protocols, it was found that chemoselective oxidation with Oxone in the presence of free radical catalyst (TEMPO), ${ }^{29}$ yielded $\alpha$-hydroxyketone 4 in (86\% yield).

Sodium borohydride reduction of ketone $\mathbf{4}$ gave exclusively trans-diol 5 in (89\% yield), which was protected as bis-p-methoxybenzyl ether 6 ( $54 \%$ yield). The acetonide group of ketal 6 was removed under acidic conditions, to furnish the resulting cis-diol 7 (75\% yield).

Chemoselective oxidation (TEMPO, Oxone) of the C-1 hydroxyl group located within the hindered pseudo-bay region of cis-diol 7 gave $\alpha$-hydroxyketone 8 (55\% yield). The alcohol group of ketone 8 was converted $\left(\mathrm{Ag}_{2} \mathrm{O} / \mathrm{MeI}\right)$ to methyl ether $\mathbf{9}$ (66\% yield).

In the final step, oxidative removal of the PMB protecting groups using DDQ gave (-)-ribisin A in (63\% yield). The spectroscopic properties of the synthetic sample were in good agreement with the natural product obtained from $P$. ribis. The synthesis of ribisin A, from dibenzofuran cis-dihydrodiol 1, was accomplished in nine steps ( $9 \%$ overall yield), a modest improvement over fourteen and eleven steps from the previous two routes. ${ }^{5-7}$

cis-Diol 3 also proved to be a versatile intermediate for the synthesis of ribisin B (Scheme 3) as all stereocentres already had the correct absolute configurations. To complete its synthesis, regisoselective $O$-methylation and alcohol oxidation to form a ketone were required.

Reaction of diol 3 with 1-(dimethoxymethyl)-4-methoxybenzene formed a mixture (57:43) of anisylidene acetal diastereoisomers 10a:10b. Due to the strong relaxation of the acetal protons $\left(\mathrm{R}^{2}\right.$ or $\left.\mathrm{R}^{1}=\mathrm{H}\right)$ by the ortho proton on the PMP group, distant nOe's were not observed and, therefore, the relative stereochemistry at the acetal stereocentre of isomers 10a and 10b could not be assigned by this method. However, the chemical shift for C-10c proton in diol 3 was 5.42 ppm while in acetals 10a and 10b the chemical shifts of the corresponding pseudobay region protons were 5.44 and $5.62 \mathrm{ppm}$ respectively. It indicates that the $p$-methoxyphenyl group of the minor acetal isomer $\mathbf{1 0 b}$ is pseudoaxial and proximate to the $\mathrm{C}-10 \mathrm{c}$ proton. This premise was tentatively used to assign the absolute configuration at the acetal centre. The difference in chemical shift $(0.32$ $\mathrm{ppm})$ of the acetal protons 10a $\left(\mathrm{R}^{2} 6.02 \mathrm{ppm}\right)$ and 10b $\left(\mathrm{R}^{1} 5.70\right.$ ppm) can be rationalised by the proximity of proton $R^{2}$ to the benzofuran ring, lending further tentative support to the stereochemical assignment.

After careful multiple elution PLC, only the minor diastereoisomer 10b could be fully separated from a small sample of the mixture. DIBAL reduction of acetal $\mathbf{1 0 b}$ gave, exclusively the unwanted PMB-ether 12. Reduction (DIBAL) of a major proportion of the original mixture of acetal diastereoisomers 10a/10b (57:43) yielded a further mixture $(58: 42)$ of readily separable alcohols 11 (30\% yield) and 12 (16\% yield).

Methylation (MeI/NaH) of alcohol 11 yielded methyl ether $\mathbf{1 3}$ ( $90 \%$ yield). The ketal group in methyl ether $\mathbf{1 3}$ was cleaved, under acidic conditions (TFA, THF, $\mathrm{H}_{2} \mathrm{O}$ ), in a similar manner to that used for acetonide 6 (Scheme 2), to form cis-diol 14 (97\% yield). The C-1 hydroxyl group group of diol 14 was chemoselectively oxidized to ketone $\mathbf{1 5}$ (catalytic TEMPO with Oxone, Scheme 3) (86\% yield). Methylation $\left(\mathrm{Ag}_{2} \mathrm{O} / \mathrm{MeI}\right)$ of the $\alpha$-hydroxy ketone 15 gave dimethoxy ketone 16 (76\% yield). Finally, the PMB protecting group was oxidatively removed (DDQ, $\mathrm{CH}_{2} \mathrm{Cl}_{2}$ ) from PMB-ether 16 to furnish (-)-ribisin B (77\% yield) giving a 10\% overall yield from cis-dihydrodiol 1 over nine steps.

As part of an earlier study of biotransformations ( $P$. putida UV4) of tricylic heteroarenes, the isolation of $c i s$-dihydrodiol metabolite $\mathbf{1}$, and its potential as a chiral synthon, was demonstrated by the synthesis and absolute configuration stereochemical assignment of diol epoxide 18, following treatment of a bromohydrin intermediate $\mathbf{1 7}$ with sodium methoxide (Scheme 4). ${ }^{27}$ The possibility of epoxide $\mathbf{1 8}$ undergoing nucleophilic attack by methoxide anion using different solvents and temperatures to yield triols 19 and 20, was examined herein (Scheme 4). Despite these changes in reaction conditions neither triol was obtained. Reactions of unactivated diol epoxides toward nucleophilic attack had been reported by using $\mathrm{Al}_{2} \mathrm{O}_{3}$ in $\mathrm{MeOH}$ solution. ${ }^{30}$ However, under similar reaction conditions, the required triol 19 was not observed among the range of unidentified products. An alternative synthetic approach to ribisin C, using intermediate $\mathbf{4}$, is currently under investigation as a chiral precursor.

\section{CONCLUSION}

The chemoenzymatic syntheses of natural products, from cisdihydrodiol metabolites, have generally been restricted to those obtained from monocyclic arene substrates. ${ }^{6-8,10-19}$ cis-Dihydrodiols of acridine and dictamnine, obtained by BPDO-catalyzed cis-dihydroxylation, were among the few examples of tricyclic arenes utilized in the chemoenzymatic synthesis of secondary metabolites. ${ }^{20}$ Following on from the innovative use of a monocyclic arene cis-dihydrodiol of bromobenzene in chemoenzymatic syntheses, ${ }^{6,7}$ this study has demonstrated that a tricyclic cis-dihydrodiol, formed by TDO-catalyzed cis-dihydroxylation of dibenzofuran, ${ }^{27}$ can also be used as a precursor for the asymmetric synthesis of the chiral dibenzofuran derivatives, ribisins A and B. This alternative approach of using a polycyclic cis-dihydrodiol precursor can now be added to the available 
methods for the synthesis of chiral natural products containing benzofuran rings. ${ }^{31}$

\section{EXPERIMENTAL SECTION}

NMR spectra were recorded on Bruker AV-400 and AV-600 instruments using specified solvents. Chemical shifts $(\delta)$ are reported in ppm relative to $\mathrm{SiMe}_{4}$ and coupling constants $(J)$ are given in Hertz $(\mathrm{Hz})$. Optical rotations $\left([\alpha]_{\mathrm{D}}\right)$ measurements $\left(10^{-}\right.$ ${ }^{1} \operatorname{deg} \mathrm{cm}^{2} \mathrm{~g}^{-1}$ ) were carried out at ambient temperature on a Perkin-Elmer 214 polarimeter and specified solvent concentration (g /100 mL) at sodium D-line (589 nm). IR spectra were recorded in $\mathrm{KBr}$ disc or in thin film. Mass spectra (ES) were recorded on an LCT Premier Mass Spectrometer. Accurate molecular weights were obtained by the peak matching method, using heptacosafluorotributylamine as the standard reference, and were accurate to within $\pm 5 \times 10^{-6}$ a.m.u. Melting points were recorded in degrees Celsius using a Stuart SMP10 melting point apparatus. Merck Kieselgel $60 \mathrm{~F}_{254}$ analytical plates were used for TLC analyses. Preparative layer chromatography (PLC) separations were carried out on glass plates $(20 \mathrm{~cm}$ x $20 \mathrm{~cm})$ coated with Merck Keiselgel $\mathrm{PF}_{254 / 366}$ silica gel (21 g silica gel in $62 \mathrm{~mL}$ water). Flash column chromatography was performed on Fluorochem silicagel 60A 40-63u.

\section{(1R,2S)-1,2-Dihydrodibenzo [b,d]furan-1,2-diol (1). ${ }^{21,27}$}

Glucose (10 g) was added to a $2000 \mathrm{~mL}$ baffled Erlenmeyer flask containing $500 \mathrm{~mL}$ of MSM culture medium, before inoculation with $P$. putida UV4. The contents were shaken at $140 \mathrm{rpm}$, at $30^{\circ} \mathrm{C}$ for $24 \mathrm{~h}$. Dibenzofuran (250 $\mathrm{mg}, 1.49 \mathrm{mmol}$ ) and glucose (2 g) were added to the mixture and it was incubated at $30^{\circ} \mathrm{C}(\mathrm{pH} 7.5-8)$ on an orbital shaker (140 rpm) for 24 - $48 \mathrm{~h}$, with further addition of glucose (2 g) after $24 \mathrm{~h}$. The cells were removed by centrifugation (7000 rpm, 15 mins) and the supernatant was concentrated in vacuo to $c a .50 \mathrm{~mL}$ before extraction with EtOAc $(3 \times 75 \mathrm{~mL})$. The combined organic extracts were concentrated to give diol $\mathbf{1}$ as a white crystalline solid (252 mg, 84\%); mp 96-98 ${ }^{\circ} \mathrm{C}$ (EtOAc/hexane); $R_{\mathrm{f}}=0.25$ (30\% EtOAc in hexane); $[\alpha]_{\mathrm{D}}+200.0(c 0.8$, $\mathrm{CHCl}_{3}$ ); HRMS (ES) calcd for $\mathrm{C}_{12} \mathrm{H}_{10} \mathrm{O}_{3} \mathrm{Na}(\mathrm{M}+\mathrm{Na})^{+} 225.0522$ found 225.0502; ${ }^{1} \mathrm{H}-\mathrm{NMR}$ (400 MHz, $\left.\mathrm{CDCl}_{3}\right): \delta 7.62(\mathrm{~m}, 1 \mathrm{H})$, 7.45 (m, 1H), 7.27 (m, 2H), 6.51 (dd, $J=10.0,2.3 \mathrm{~Hz}, 1 \mathrm{H}$ ), 6.05 (ddd, $J=10.0,2.5,0.7 \mathrm{~Hz}, 1 \mathrm{H}$ ), $4.96(\mathrm{dd}, J=6.3,0.7 \mathrm{~Hz}, 1 \mathrm{H}$ ), 4.67 (dt, $J=6.3,2.5 \mathrm{~Hz}, 1 \mathrm{H}$ ), 2.48 (br s, $2 \mathrm{H}$ ); ${ }^{13} \mathrm{C}-\mathrm{NMR}$ (100 MHz, $\left.\mathrm{CDCl}_{3}\right): \delta$ 155.1, 152.0, 134.3, 126.5, 124.6, 123.6, 119.2, 117.4, 113.5, 111.7, 70.8, 65.1. Spectroscopic data matched literature values.

(3aR,10cS)-2,2-Dimethyl-3a,10c-dihydrobenzo[b][1,3]diox-

olo[4,5-e]benzofuran (2). ${ }^{22}$ To a stirring solution of cis-dihydrodiol $1(270 \mathrm{mg}, 1.34 \mathrm{mmol})$ in a mixture of acetone $(6 \mathrm{~mL})$ and 2,2DMP $(6 \mathrm{~mL})$, maintained at $0^{\circ} \mathrm{C}$, was added pyridinium $p$-toluenesulfonate $(234 \mathrm{mg}, 0.93 \mathrm{mmol})$. The reaction mixture was stirred $(2 \mathrm{~h})$ at $0^{\circ} \mathrm{C}$ and then at room temperature for $12 \mathrm{~h}$. After the addition of a saturated aqueous solution of $\mathrm{NaHCO}_{3}(5 \mathrm{~mL})$, the mixture was concentrated under reduced pressure and the concentrate extracted with EtOAc $(2 \times 15 \mathrm{~mL})$. The organic phase was dried $\left(\mathrm{Na}_{2} \mathrm{SO}_{4}\right)$, concentrated and the crude product purified by flash column chromatography (4\% EtOAc in hexane), to afford acetonide 2, a white solid, (237 mg, 73\%); $R_{\mathrm{f}}=0.45$ (10\% EtOAc in hexane); $[\alpha]_{\mathrm{D}}+130.8$ (c 0.66, $\mathrm{CHCl}_{3}$ ); HRMS (ES) calcd for $\mathrm{C}_{15} \mathrm{H}_{14} \mathrm{O}_{3} \mathrm{Na}(\mathrm{M}+\mathrm{Na})^{+} 265.0836$ found $265.0841 ;{ }^{1} \mathrm{H}-\mathrm{NMR}(400$ $\left.\mathrm{MHz}, \mathrm{CDCl}_{3}\right): \delta 7.65$ (m, 1H), $7.45(\mathrm{~m}, 1 \mathrm{H}), 7.26(\mathrm{~m}, 2 \mathrm{H}), 6.57$ (dd, $J=10.0,1.3 \mathrm{~Hz}, 1 \mathrm{H}$ ), 6.08 (dd, $J=10.0,3.5 \mathrm{~Hz}, 1 \mathrm{H}$ ), 5.43 (d, $J=8.3 \mathrm{~Hz}, 1 \mathrm{H}$ ), 5.00 (ddd, $J=8.3,3.5,1.3 \mathrm{~Hz}, 1 \mathrm{H}), 1.52$ (3H, s, Me), 1.38 (3H, s, Me); ${ }^{13} \mathrm{C}-\mathrm{NMR}\left(100 \mathrm{MHz}, \mathrm{CDCl}_{3}\right): \delta$ 155.1, $151.3,129.2,127.1,124.5,123.5,119.5,118.0,111.6,111.0$,
106.6, 73.0, 69.6, 27.0, 25.1; IR $v_{\max } / \mathrm{cm}^{-1} 2068,1935,1446.1 \mathrm{H}$ NMR data was in good agreement with literature values.

The decomposition product, dibenzo[b,d]furan-2-ol (27 mg, 11\%), was also isolated from the crude product. NMR data in good agreement with literature values. ${ }^{32}{ }^{1} \mathrm{H}-\mathrm{NMR}\left(400 \mathrm{MHz}, \mathrm{CDCl}_{3}\right) \delta_{\mathrm{H}} 7.86$ (d, J = 7.8 Hz, 1H), 7.53 (d, J = 8.2 Hz, 1H), 7.44 ( td, J = 7.1, 1.3 $\mathrm{Hz}, 1 \mathrm{H}), 7.42(\mathrm{~d}, \mathrm{~J}=8.8 \mathrm{~Hz}, 1 \mathrm{H}), 7.36(\mathrm{~d}, \mathrm{~J}=2.7 \mathrm{~Hz}, 1 \mathrm{H}), 7.30$ (1H, td, J = 7.5, 0.9 Hz, H), 6.95 (1H, dd, J = 8.8, 2.7 Hz, 1H), 4.98 $\left(1 \mathrm{H}\right.$, br s, OH); ${ }^{13} \mathrm{C}-\mathrm{NMR}\left(100 \mathrm{MHz}, \mathrm{CDCl}_{3}\right) \delta_{\mathrm{c}} 157.0,151.5$, $151.0,127.3,125.1,124.2$, 122.5, 120.7, 115.3, 112.1, 111.8, 106.3.

(3aS,4R,5S,10cR)-2,2-Dimethyl-3a,4,5,10c-tetrahydro-

benzo[b][1,3]dioxolo[4,5-e]benzofuran-4,5-diol (3). To a stirred solution of acetonide 2 (17.5 mg, $0.072 \mathrm{mmol})$ and $N$-methylmorpholine- $N$-oxide $(10.0 \mathrm{mg})$, in a mixture of acetone $(4.5 \mathrm{~mL})$ and water $(0.5 \mathrm{~mL})$, maintained at $0^{\circ} \mathrm{C}$, was added a solution of osmium tetroxide in ${ }^{\mathrm{t}} \mathrm{BuOH}(2.5 \mathrm{wt} \%, 70 \mu \mathrm{l})$. After stirring the reaction mixture overnight at room temperature, a saturated aqueous solution of $\mathrm{Na}_{2} \mathrm{~S}_{2} \mathrm{O}_{5}(1 \mathrm{~mL})$ was added to it and the stirring continued for another 10 mins. The reaction mixture was concentrated in vacuo, water $(2 \mathrm{~mL})$ added to it, the mixture thoroughly extracted with EtOAc $(2 \times 5 \mathrm{~mL})$ and the organic extract was dried $\left(\mathrm{Na}_{2} \mathrm{SO}_{4}\right)$ and concentrated. The crude product obtained was purified by flash column chromatography (60\% EtOAc in hexane) to afford cis-diol 3 (18.2 mg, 91\%), a white solid, $R_{\mathrm{f}}=0.18$ (40\% EtOAc in hexane); $[\alpha]_{\mathrm{D}}+30.6$ ( $c$ 0.36, MeOH); HRMS (ES) calcd for $\mathrm{C}_{15} \mathrm{H}_{16} \mathrm{O}_{5} \mathrm{Na}(\mathrm{M}$ $+\mathrm{Na})^{+} 299.0887$ found 299.0895; ${ }^{1} \mathrm{H}-\mathrm{NMR}\left(400 \mathrm{MHz}, \mathrm{CDCl}_{3}\right): \delta$ $7.67(\mathrm{~m}, 1 \mathrm{H}), 7.50(\mathrm{~m}, 1 \mathrm{H}), 7.33(\mathrm{dt}, J=7.3,1.3 \mathrm{~Hz}, 1 \mathrm{H}), 7.28$ (dt, $J=7.5,1.3 \mathrm{~Hz}, 1 \mathrm{H}$ ), 5.42 (d, $J=5.5 \mathrm{~Hz}, 1 \mathrm{H}), 5.02$ (d, $J=3.9 \mathrm{~Hz}$, $1 \mathrm{H}), 4.60$ (dd, $J=7.3,5.5 \mathrm{~Hz}, 1 \mathrm{H}), 4.26$ (dd, $J=7.3,3.9 \mathrm{~Hz}, 1 \mathrm{H})$, 2.88 (br s, 1H), 2.76 (br s, 1H), 1.52 (3H, s, Me), 1.41 (3H, s, Me).

${ }^{13} \mathrm{C}-\mathrm{NMR}\left(100 \mathrm{MHz}, \mathrm{CDCl}_{3}\right): \delta$ 155.9, 151.9, 126.4, 125.3, 123.4, 120.2, 113.0, 111.8, 111.0, 71.8, 69.5, 64.0, 29.7, 28.21, 26.3; IR $v_{\max } / \mathrm{cm}^{-1}$ 3454, 2988, 2935, 1958, 1630, 1245.

(3aS,4S,10cR)-4-Hydroxy-2,2-dimethyl-3a,4-dihydrobenzo[b][1,3]dioxolo[4,5-e]benzofuran-5(10cH)-one

(4). A stirred solution of acetonide diol 3 (20 mg, $0.072 \mathrm{mmol})$ containing tetrabutylammonium bromide $(1 \mathrm{mg})$ in dry $\mathrm{CH}_{2} \mathrm{Cl}_{2}(2 \mathrm{~mL})$ was treated with TEMPO (1 mg) and Oxone (55 mg, $0.18 \mathrm{mmol})$. The reaction mixture was stirred overnight at room temperature, concentration under reduced pressure and the crude material purified by flash column chromatography (20\% EtOAc in hexane), to give hydroxy ketone $4(17.2 \mathrm{mg}, 86 \%)$, a white solid; $R_{\mathrm{f}} 0.21$ (30\% EtOAc in hexane); $[\alpha]_{\mathrm{D}}+35.0$ (c 0.8, $\left.\mathrm{CHCl}_{3}\right)$; HRMS (ES) calcd for $\mathrm{C}_{15} \mathrm{H}_{15} \mathrm{O}_{5}(\mathrm{M}+\mathrm{H})^{+} 275.0919$ found 275.0922; ${ }^{1} \mathrm{H}-\mathrm{NMR}(600$ $\left.\mathrm{MHz}, \mathrm{CDCl}_{3}\right): \delta 7.85$ (d, $\left.J=7.8 \mathrm{~Hz}, 1 \mathrm{H}\right), 7.63(\mathrm{~d}, J=8.6 \mathrm{~Hz}, 1 \mathrm{H})$, 7.58 (dt, $J=7.2,1.2 \mathrm{~Hz}, 1 \mathrm{H}), 7.43$ (dt, $J=7.2,1.0 \mathrm{~Hz}, 2 \mathrm{H}), 5.58$ (d, $J=5.0 \mathrm{~Hz}, 1 \mathrm{H}), 4.73-4.68$ (m, 1H), 3.58 (br s, $1 \mathrm{H}), 1.59$ (s, Me), 1.57 (s, Me); ${ }^{13} \mathrm{C}-\mathrm{NMR}\left(150 \mathrm{MHz}, \mathrm{CDCl}_{3}\right): \delta 185.4,157.4,146.0$, 130.1, 128.1, 125.5, 124.8, 122.3, 113.1, 112.9, 81.5, 76.4, 68.4, 28.1, 26.5; IR $v_{\max } / \mathrm{cm}^{-1} 3430,3089,3066,2990,2810,1711,1597$, 1542, 1216, 1065, 1001, 900.

(3aS, 4R,5R,10cR)-2,2-Dimethyl-3a,4,5,10c-tetrahydrobenzo[b][1,3]dioxolo[4,5-e]benzofuran-4,5-diol (5). An icecooled solution of hydroxyketone 4 (205 mg, $0.75 \mathrm{mmol}$ ) in $\mathrm{MeOH}$ $(10 \mathrm{~mL})$ was treated with sodium borohydride $(57 \mathrm{mg}, 1.5 \mathrm{mmol})$ and the mixture stirred $(0.5 \mathrm{~h})$ at room temperature. The concentrate obtained after removal of solvent was dissolved in $\mathrm{CH}_{2} \mathrm{Cl}_{2}(20$ $\mathrm{mL})$, washed with $1 \mathrm{M} \mathrm{HCl}(5 \mathrm{~mL})$ and the aqueous washing extracted with $\mathrm{CH}_{2} \mathrm{Cl}_{2}(2 \times 5 \mathrm{~mL})$. The combined organic phase was dried $\left(\mathrm{MgSO}_{4}\right)$ and concentrated to afford a pure sample of transdiol 5 (184 mg, 89\%), a white solid; $R_{\mathrm{f}}=0.25$ (50\% EtOAc in hexane); $[\alpha]_{\mathrm{D}}+35.9\left(c\right.$ 1.0, $\mathrm{CHCl}_{3}$ ); HRMS (ES) calcd for $\mathrm{C}_{15} \mathrm{H}_{20} \mathrm{NO}_{5}$ $\left(\mathrm{M}+\mathrm{NH}_{4}\right)^{+} 294.1341$ found 294.1355; ${ }^{1} \mathrm{H}-\mathrm{NMR}(600 \mathrm{MHz}$, $\left.\mathrm{CDCl}_{3}\right): \delta 7.65$ (d, $\left.J=7.6 \mathrm{~Hz}, 1 \mathrm{H}\right), 7.50$ (d, $\left.J=8.1 \mathrm{~Hz}, 1 \mathrm{H}\right), 7.32$ 
(dt, $J=7.5,1.4 \mathrm{~Hz}, 1 \mathrm{H}), 7.27$ (dt, $J=7.6,1.0 \mathrm{~Hz}, 1 \mathrm{H}), 5.39$ (d, $J=$ $5.4 \mathrm{~Hz}, 1 \mathrm{H}), 4.79$ (d, $J=5.9 \mathrm{~Hz}, 1 \mathrm{H}), 4.49$ (dd, $J=6.9,5.5 \mathrm{~Hz}$, $1 \mathrm{H}$ ), 4.31 (dd, $J=6.9,5.9 \mathrm{~Hz}, 1 \mathrm{H}$ ), 3.33 (br s, 1H), 2.95 (br s, 1H), 1.50 (s, Me), 1.41 (s, Me); ${ }^{13} \mathrm{C}-\mathrm{NMR}\left(150 \mathrm{MHz}, \mathrm{CDCl}_{3}\right): \delta 155.9$, 152.5, 126.4, 125.1, 123.4, 120.1, 111.8, 111.7, 111.6, 78.3, 74.3, 69.5, 67.6, 28.3, 26.5; IR $v_{\max } / \mathrm{cm}^{-1} 3498,2998,2902,1967,1629$, 1220.

(3aR, 4S, 5R, 10cR)-4,5-bis((4-methoxybenzyl)oxy)-2,2-Dimethyl3a,4,5,10c-tetrahydrobenzo[b][1,3]dioxolo[4,5-e]benzofuran (6). To a solution of trans-diol 5 (18 mg, $0.065 \mathrm{mmol})$ and 4-methoxybenzyl-2,2,2-trichloroacetimidate $(92 \mathrm{mg})$ in toluene $(4 \mathrm{~mL})$ was added lanthanum (III) triflate $(7.6 \mathrm{mg})$. After stirring (5 mins) the reaction mixture at room temperature, the solvent was removed in vacuo and the crude product purified by PLC (10\% EtOAc in hexane), to furnish methoxybenzyl ether 6 (18 $\mathrm{mg}, 54 \%$ ), a paleyellow oil; $R_{\mathrm{f}} 0.25$ (20\% EtOAc in hexane); $[\alpha]_{\mathrm{D}}+23.6(c$ 1.2, $\mathrm{CHCl}_{3}$ ); HRMS (ES) calcd for $\mathrm{C}_{31} \mathrm{H}_{32} \mathrm{O}_{7} \mathrm{Na}(\mathrm{M}+\mathrm{Na})^{+} 539.2046$ found 539.2048; ${ }^{1} \mathrm{H}-\mathrm{NMR}\left(600 \mathrm{MHz}, \mathrm{CDCl}_{3}\right): \delta 7.65$ (d, $J=7.6$ $\mathrm{Hz}, 1 \mathrm{H}), 7.50$ (d, $J=8.2 \mathrm{~Hz}, 1 \mathrm{H}), 7.39$ (d, $J=8.5 \mathrm{~Hz}, 2 \mathrm{H}), 7.32$ (td, $J=7.61 .2 \mathrm{~Hz}, 1 \mathrm{H}) 7.29-7.25(\mathrm{~m}, 3 \mathrm{H}), 6.90$ (d, $J=8.5 \mathrm{~Hz}$, 2H), $6.86(\mathrm{~d}, J=8.5 \mathrm{~Hz}, 1 \mathrm{H}), 5.35(\mathrm{~d}, J=5.7 \mathrm{~Hz}, 1 \mathrm{H}), 4.96$ (d, $J=11.2 \mathrm{~Hz}, 1 \mathrm{H}), 4.80$ (d, $J=11.2 \mathrm{~Hz}, 1 \mathrm{H}), 4.76$ (d, $J=11.1$ $\mathrm{Hz}, 1 \mathrm{H}), 4.69(\mathrm{~d}, J=11.1 \mathrm{~Hz}, 1 \mathrm{H}), 4.67(1 \mathrm{H}, \mathrm{d}, J=5.8 \mathrm{~Hz}, 1 \mathrm{H})$, 4.51 (1H, dd, $J=6.9,5.8 \mathrm{~Hz}, \mathrm{H}-3 \mathrm{a}$ ), 4.13 (dd, $J=6.9,5.8 \mathrm{~Hz}$, $\mathrm{H}-4$ ), 3.82 (s, Me), 3.80 (s, Me), 1.50 (s, Me), 1.40 (s, $1 \mathrm{H}) ;{ }^{13} \mathrm{C}-$ NMR (150 MHz, $\left.\mathrm{CDCl}_{3}\right): \delta 159.4$ (4), 155.9, 153.0, 130.2 (2), 129.8, 126.5, 124.9, 123.2, 120.0, 113.8 (4), 112.2, 111.7, 111.2, 80.2, 78.2, 73.9, 72.9, 72.7, 69.3, 55.3 (2), 28.2, 26.2; IR $v_{\max } / \mathrm{cm}^{-1}$ 2968, 2931, 2844, 1520, 1261, 1107, 871.

(1R,2R,3S,4R)-3,4-bis((4-methoxybenzyl)oxy)-1,2,3,4-Tetrahydrodibenzo[b,d]furan-1,2-diol (7). A solution of methoxybenzyl ether 6 (18 mg, $0.035 \mathrm{mmol})$ in THF- $\mathrm{H}_{2} \mathrm{O}(4: 1,3 \mathrm{~mL})$ was treated with TFA $(70 \mu \mathrm{L})$. The reaction mixture was stirred $(40$ h) at $60^{\circ} \mathrm{C}$, concentrated under reduced pressure, and the crude product purified by flash column chromatography (40\% EtOAc in hexane), to give cis-diol 7 (12.5 mg, 75\%), a colorless oil; $R_{\mathrm{f}}$ 0.22 (50\% EtOAc in hexane); $[\alpha]_{\mathrm{D}}+19.0$ ( $c$ 1.3, $\mathrm{CHCl}_{3}$ ); HRMS (ES) calcd for $\mathrm{C}_{28} \mathrm{H}_{28} \mathrm{O}_{7} \mathrm{Na}(\mathrm{M}+\mathrm{Na})^{+} 499.1733$ found 499.1732; ${ }^{1} \mathrm{H}-\mathrm{NMR}\left(400 \mathrm{MHz}, \mathrm{CDCl}_{3}\right): \delta 7.77$ (d, $\left.J=7.6 \mathrm{~Hz}, 1 \mathrm{H}\right), 7.50$ (d, $J=8.2 \mathrm{~Hz}, 1 \mathrm{H}), 7.35-7.30(\mathrm{~m}, 3 \mathrm{H}), 7.27(\mathrm{td}, J=7.7,0.9 \mathrm{~Hz}$, 1H) 7.21 (d, $J=8.6 \mathrm{~Hz}, 2 \mathrm{H}), 6.90(\mathrm{~d}, J=8.6 \mathrm{~Hz}, 2 \mathrm{H}), 6.86$ (d, $J=8.7 \mathrm{~Hz}, 2 \mathrm{H}), 5.08$ (dd, $J=6.8,4.2 \mathrm{~Hz}, 1 \mathrm{H}), 4.91$ (d, $J=11.2$ $\mathrm{Hz}, 1 \mathrm{H}), 4.74$ (d, $J=11.2 \mathrm{~Hz}, 1 \mathrm{H}), 4.73$ (d, $J=11.4 \mathrm{~Hz}, 1 \mathrm{H})$, $4.70(\mathrm{~d}, J=4.7 \mathrm{~Hz}, 1 \mathrm{H}), 4.59$ (d, $J=11.4 \mathrm{~Hz}, 1 \mathrm{H}), 4.22(1 \mathrm{H}$, dd, $J=7.0,4.2 \mathrm{~Hz}, 1 \mathrm{H}$ ), 4.03 (ddd, $J=10.5,6.4,4.2 \mathrm{~Hz}, 1 \mathrm{H}$ ), 3.82 (s, Me), 3.80 (s, Me); ${ }^{13} \mathrm{C}-\mathrm{NMR}$ (150 MHz, $\left.\mathrm{CDCl}_{3}\right): \delta$ 159.6 (2), 155.9, 151.3, 129.8 (2), 129.7, 129.6 (2), 129.4, 126.8, 125.0, 123.2, 120.9, 115.9, 114.0 (4), 111.6, 77.9, 73.5, 73.2, 72.4, 70.4, 64.3, 55.4 (2); IR $v_{\max } / \mathrm{cm}^{-1} 3996,2954,2917$, 2849, 1575, 1542, 1249, 1089, 1011.

(2S,3S,4R)-2-Hydroxy-3,4-bis((4-methoxybenzyl)oxy)-3,4-dihydrodibenzo[b,d]furan-1 $(2 \mathrm{H})$-one (8). To a stirred solution of cis-diol 7 (12 mg, $0.025 \mathrm{mmol}$ ), containing tetrabutylammonium bromide $(1 \mathrm{mg})$ in dry $\mathrm{CH}_{2} \mathrm{Cl}_{2}(2 \mathrm{~mL})$, was added TEMPO $(1 \mathrm{mg})$ and Oxone (18 $\mathrm{mg}, 0.06 \mathrm{mmol})$. After stirring the reaction mixture, overnight at room temperature, the solvent was removed in vacou and the crude product purified by flash column chromatography (30\% EtOAc in hexane), to afford $\alpha$-hydroxyketone 8 (6.6 mg, 55\%), a white solid; $R_{\mathrm{f}} 0.30(30 \%$ EtOAc in hexane); $[\alpha]_{\mathrm{D}}+34.0\left(c\right.$ 0.7, $\left.\mathrm{CHCl}_{3}\right)$; HRMS (ES) calcd for $\mathrm{C}_{28} \mathrm{H}_{26} \mathrm{O}_{7} \mathrm{Na}(\mathrm{M}+\mathrm{Na})^{+} 497.1576$ found 497.1506 ; ${ }^{1} \mathrm{H}-\mathrm{NMR}$ (400 MHz, $\left.\mathrm{CDCl}_{3}\right): \delta 8.03(\mathrm{~m}, 1 \mathrm{H}), 7.57(\mathrm{~m}, 1 \mathrm{H}), 7.44-7.34(\mathrm{~m}$, $6 \mathrm{H}), 6.91$ (d, $J=8.6 \mathrm{~Hz}, 2 \mathrm{H}), 6.88$ (d, $J=8.6 \mathrm{~Hz}, 2 \mathrm{H}$ ), 5.10 (d, $J=10.9 \mathrm{~Hz}, 1 \mathrm{H}), 5.01(\mathrm{~d}, J=10.7 \mathrm{~Hz}, 1 \mathrm{H}), 4.98(\mathrm{~d}, J=7.9 \mathrm{~Hz}$,
1H), 4.94 (d, $J=10.9 \mathrm{~Hz}, 1 \mathrm{H}), 4.83$ (d, $J=10.7 \mathrm{~Hz}, 1 \mathrm{H}), 4.45$ (dd, $J=9.8,1.9 \mathrm{~Hz}, 1 \mathrm{H}), 4.06$ (dd, $J=9.8,7.9 \mathrm{~Hz}, 1 \mathrm{H}), 3.82$ (s, Me), 3.81 (s, Me), 3.80 (d, $J=2.0 \mathrm{~Hz}, 1 \mathrm{H}) ;{ }^{13} \mathrm{C}-\mathrm{NMR}(150$ $\mathrm{MHz}, \mathrm{CDCl}_{3}$ ): $\delta 191.0,167.4,159.4$ (2), 156.2, 130.0 (4), 129.6, 126.3, 125.1, 122.3, 122.0, 114.9, 113.9 (4), 111.9, 85.8, 77.8, 75.2, 75.1, 75.1, 74.7, 55.3 (2); IR $v_{\max } / \mathrm{cm}^{-1} 3453$, 3070, 2927, 2852, 2778, 1771, 1707, 1625, 1515, 1366, 1169, 1014.

(2S,3R,4R)-2-Methoxy-3,4-bis((4-methoxybenzyl)oxy)-3,4-dihydrodibenzo[b,d]furan-1(2H)-one (9). A glass tube, containing a mixture of $\alpha$-hydroxyketone 8 (6.5 $\mathrm{mg}, 0.014 \mathrm{mmol}$ ), $\mathrm{Ag}_{2} \mathrm{O}(12 \mathrm{mg})$ and MeI $(10 \mu \mathrm{L})$ in dry THF $(2 \mathrm{~mL})$, was sealed under argon and the mixture stirred $(24 \mathrm{~h})$ at $60^{\circ} \mathrm{C}$. The solvent was removed in vacuo and the crude product purified by flash column chromatography (15\% EtOAc in hexane) to yield methyl ether 9 ( $4.4 \mathrm{mg}, 66 \%$ ), a colorless oil; $R_{\mathrm{f}} 0.24$ (20\% EtOAc in hexane); $[\alpha]_{\mathrm{D}}+47.7$ ( $c$ 0.4, $\mathrm{CHCl}_{3}$ ); HRMS (ES) calcd for $\mathrm{C}_{29} \mathrm{H}_{32} \mathrm{NO}_{7}\left(\mathrm{M}+\mathrm{NH}_{4}\right)^{+} 506.2179$ found 506.2220; ${ }^{1} \mathrm{H}-\mathrm{NMR}$ (400 MHz, $\left.\mathrm{CDCl}_{3}\right): \delta 8.06$ (d, $\left.J=7.2 \mathrm{~Hz}, 1 \mathrm{H}\right), 7.55$ (d, $J=7.8$ $\mathrm{Hz}, 1 \mathrm{H}), 7.43-7.28$ (m, 6H), 6.91 (d, $J=8.8 \mathrm{~Hz}, 2 \mathrm{H}), 6.89$ (d, $J$ $=8.8 \mathrm{~Hz}, 2 \mathrm{H}), 5.05(\mathrm{~d}, J=11.1 \mathrm{~Hz}, 1 \mathrm{H}), 4.95-4.88(\mathrm{~m}, 2 \mathrm{H})$, 4.86 (d, $J=10.7 \mathrm{~Hz}, 1 \mathrm{H}), 4.75$ (d, $J=10.7 \mathrm{~Hz}, 1 \mathrm{H}), 4.14$ (dd, $J$ = 9.3, 7.3 Hz, 1H), 3.99 (d, $J=9.3 \mathrm{~Hz}, 1 \mathrm{H}), 3.83$ (s, Me), 3.82 (s, Me), 3.77 (3H, s, Me); ${ }^{13} \mathrm{C}-\mathrm{NMR}$ (150 MHz, $\left.\mathrm{CDCl}_{3}\right): \delta$ 190.6, 165.9, 159.6, 159.5, 156.1, 130.2, 129.9, 129.5, 126.2, 124.9, 122.8, 122.3, 115.9, 113.9, 111.7, 86.2, 83.7, 75.3, 74.8, 74.3, 61.0, 55.3; IR $v_{\max } / \mathrm{cm}^{-1} 2969,2882,1735,1679,1280$, 1021, 976

(2S,3R,4R)-3,4-Dihydroxy-2-methoxy-3,4-dihydrodi-

benzo[b, d]furan-1 $(2 H)$-one (Ribisin A). ${ }^{1,7}$ To a solution of methyl ether 9 (9.0 mg, $0.018 \mathrm{mmol}$ ) in a mixture of $\mathrm{CH}_{2} \mathrm{Cl}_{2}$ and $\mathrm{H}_{2} \mathrm{O}(4: 1,2 \mathrm{~mL})$ was added DDQ $(12.5 \mathrm{mg})$ and the mixture stirred $(18 \mathrm{~h})$ at room temperature. Water $(2 \mathrm{~mL})$ and $\mathrm{CH}_{2} \mathrm{Cl}_{2}(5$ $\mathrm{mL}$ ) were added to the stirring mixture, the organic phase separated, and the remaining aqueous phase extracted with $\mathrm{CH}_{2} \mathrm{Cl}_{2}$ $(5 \mathrm{~mL})$. The combined organic extract was dried $\left(\mathrm{MgSO}_{4}\right)$, concentrated, and the residue obtained was purified by flash column chromatography (50\% EtOAc in hexane) to afford ribisin A (2.9 mg, 63\%), a pale-yellow solid; $R_{\mathrm{f}}=0.20$ (60\% EtOAc in hexane); $[\alpha]_{\mathrm{D}}-16.0$ (c 0.2, MeOH); HRMS (ES) calcd for $\mathrm{C}_{26} \mathrm{H}_{24} \mathrm{O}_{10} \mathrm{Na}(2 \mathrm{M}+\mathrm{Na})^{+} 519.1267$ found 519.1259; ${ }^{1} \mathrm{H}-\mathrm{NMR}$ $\left(600 \mathrm{MHz}, \mathrm{CDCl}_{3}\right): \delta 7.93(\mathrm{dm}, J=7.6 \mathrm{~Hz}, 1 \mathrm{H}), 7.56(\mathrm{dm}, J=$ $8.1 \mathrm{~Hz}, 1 \mathrm{H}), 7.36$ (dt, $J=7.4,1.4 \mathrm{~Hz}, 1 \mathrm{H}), 7.32$ (dt, $J=7.6,1.0$ Hz, 1H), 4.93 (d, $J=7.6 \mathrm{~Hz}, 1 \mathrm{H}), 3.97$ (d, $J=9.9 \mathrm{~Hz}, 1 \mathrm{H}), 3.92$ (dd, $J=9.9,7.6 \mathrm{~Hz}, 1 \mathrm{H}), 3.66$ (s, OMe); ${ }^{13} \mathrm{C}-\mathrm{NMR}(150 \mathrm{MHz}$, $\left.\mathrm{CDCl}_{3}\right): \delta 91.3,169.4,157.6,127.2,126.0,124.3,122.9,116.1$, 112.8, 87.2, 78.9, 70.4, 60.8 .

(3aR,3bS,5S,6aS, 11cR)-5-(4-methoxyphenyl)-2,2-Dimethyl$3 a, 3 b, 6 a, 11$ c-tetrahydrobenzo[4', 5'] furo [2', 3':5, 6] benzo[1,2$\left.d: 3,4-d^{\prime}\right] b i s([1,3]$ dioxole) and $(3 a R, 3 b S, 5 R, 6 a S, 11 c R)-5-(4-$ methoxyphenyl)-2,2-Dimethyl-3a,3b,6a,11c-tetrahydrobenzo[4',5']furo[2',3':5,6] benzo[1,2-d:3,4-d'] bis([1,3]dioxole) (10a and 10b). To an ice-cooled solution of cis-diol 3 (40 mg, $0.145 \mathrm{mmol}$ ) and 1-(dimethoxymethyl)-4-methoxybenzene $(0.10 \mathrm{~mL})$ in dry $\mathrm{CH}_{2} \mathrm{Cl}_{2}(3 \mathrm{~mL})$ was added $(+)-10$-camphorsulfonic acid (14 mg). The reaction mixture was stirred $(3 \mathrm{~h})$ at $0^{\circ} \mathrm{C}$, warmed to room temperature and treated with saturated aqueous solution of $\mathrm{NaHCO}_{3}(2 \mathrm{~mL})$. The organic phase was separated, the remaining aqueous solution extracted with $\mathrm{CH}_{2} \mathrm{Cl}_{2}(2 \times 3 \mathrm{~mL})$, and the combined organic solution dried $\left(\mathrm{MgSO}_{4}\right)$ and concentrated. The resulting yellow oil was purified by flash column chromatography (8\% EtOAc in hexane) to give a mixture of acetals 10a and 10b (57:43) as a pale-yellow oil (50 mg, 87\%); $R_{\mathrm{f}}=0.23$ (5\% EtOAc in hexane); HRMS (ES) 
calcd for $\mathrm{C}_{23} \mathrm{H}_{22} \mathrm{O}_{6} \mathrm{Na}(\mathrm{M}+\mathrm{Na})^{+} 417.1314$ found 417.1309; Minor diastereoisomer 10b: ${ }^{1} \mathrm{H}-\mathrm{NMR}\left(400 \mathrm{MHz}, \mathrm{CDCl}_{3}\right): \delta 7.74$ (dm, $J=6.9 \mathrm{~Hz}, 11 \mathrm{H}), 7.51(\mathrm{dm}, J=7.1 \mathrm{~Hz}, 8 \mathrm{H}), 7.40-7.27(\mathrm{~m}$, 9H, 10H), 7.14 (d, $J=8.7 \mathrm{~Hz}, 2$ x PMB-ArH), 6.76 (d, $J=8.7$ Hz, 2 x PMB-ArH), 6.02 (s, 5H), 5.44 (d, $J=5.1 \mathrm{~Hz}, 11 \mathrm{Hc}$ ), 5.39 (d, $J=6.5 \mathrm{~Hz}, 6 \mathrm{Ha}$ ), 5.01 (dd, $J=6.5,2.8 \mathrm{~Hz}, 3 \mathrm{Hb}$ ), 4.91 (dd, $J=5.1,2.8 \mathrm{~Hz}, 3 \mathrm{Ha}$ ), 3.72 (s, OMe), 1.46 (s, Me), 1.12 (s, Me). Major diastereoisomer 10a: ${ }^{1} \mathrm{H}-\mathrm{NMR}\left(400 \mathrm{MHz}, \mathrm{CDCl}_{3}\right)$ : $\delta 7.76(\mathrm{dm}, J=7.3 \mathrm{~Hz}, 11 \mathrm{H}), 7.54(\mathrm{dm}, J=7.7 \mathrm{~Hz}, 8 \mathrm{H}), 7.39$ (d, $J=8.7 \mathrm{~Hz}, 2$ x PMB-ArH), 7.37-7.27 (m, 9H, 10H), 5.70 (s, $5 \mathrm{H}), 5.62$ (d, $J=5.8 \mathrm{~Hz}, 11 \mathrm{Hc}$ ), 5.51 (d, $J=4.9 \mathrm{~Hz}, 6 \mathrm{Ha}$ ), 5.01 (dd, $J=5.8,3.0 \mathrm{~Hz}, 3 \mathrm{Hb}$ ), 4.91 (dd, $J=5.0,3.0 \mathrm{~Hz}, 3 \mathrm{Ha}$ ), 3.81 (s, OMe), 1.45 (s, Me), 1.09 (s, Me).

\section{(3aS, 4S, 5S, 10cR)-5-((4-methoxybenzyl)oxy)-2,2-Dimethyl-} $3 a, 4,5,10$ c-tetrahydrobenzo[b] [1,3]dioxolo[4,5-e]benzofuran4-ol (11) and (3aR,4R,5S,10cR)-4-((4-methoxybenzyl)oxy)-2,2Dimethyl-3a,4,5,10c-tetrahydrobenzo $[b][1,3]$ dioxolo $[4,5$ e]benzofuran-5-ol (12). To a solution of cis-diol 3 (120 mg, $0.43 \mathrm{mmol}$ ) and (+)-camphorsulfonic acid (40 mg), in dry $\mathrm{CH}_{2} \mathrm{Cl}_{2}(5 \mathrm{~mL})$ maintained at $-15^{\circ} \mathrm{C}$, was 1-(dimethoxymethyl)4-methoxybenzene $(0.30 \mathrm{~mL}, 1.6 \mathrm{mmol})$. After stirring $(4 \mathrm{~h})$ the reaction mixture it was diluted with $\mathrm{CH}_{2} \mathrm{Cl}_{2}(10 \mathrm{~mL})$, allowed to worm up to room temperature and washed with a saturated aqueous solution of $\mathrm{NaHCO}_{3}(10 \mathrm{~mL})$. The organic phase was dried $\left(\mathrm{MgSO}_{4}\right)$ and concentrated in vacuo to give a mixture of diastereomers 10a and 10b. The mixture of diastereomers was taken up in dry $\mathrm{CH}_{2} \mathrm{Cl}_{2}(10 \mathrm{~mL})$, cooled to $-78^{\circ} \mathrm{C}$ and treated with a solution of DIBAL $(1 \mathrm{M}, 4.3 \mathrm{~mL})$ in hexane. The mixture was kept stirred $(6 \mathrm{~h})$ at $-78^{\circ} \mathrm{C}$, allowed to warm to room temperature, and a saturated aqueous solution of potassium sodium tartrate $(2 \mathrm{~mL})$ added to it. After stirring the reaction mixture overnight, the organic phase was separated and the remaining aqueous phase extracted with $\mathrm{CH}_{2} \mathrm{Cl}_{2}(5 \mathrm{~mL})$. The combined organic extract was dried $\left(\mathrm{MgSO}_{4}\right)$ and concentrated. The crude product obtained was purified by flash column chromatography (25\% EtOAc in hexane) to give benzylic ether 11, a pale-yellow solid, and homobenzylic ether 12, a pale-yellow oil.

Benzylic ether 11 (52 mg, 30\%); $R_{\mathrm{f}} 0.21$ (30\% EtOAc in hexane); $[\alpha]_{\mathrm{D}}+8.4$ (c 1.5, $\mathrm{CHCl}_{3}$ ); HRMS (ES) calcd for $\mathrm{C}_{23} \mathrm{H}_{28} \mathrm{NO}_{6}\left(\mathrm{M}+\mathrm{NH}_{4}\right)^{+} 414.1917$ found 414.1928; ${ }^{1} \mathrm{H}-\mathrm{NMR}$ $\left(600 \mathrm{MHz}_{\mathrm{CDCl}}\right): \delta 7.65(\mathrm{~d}, J=3.9 \mathrm{~Hz}, 1 \mathrm{H}), 7.48(\mathrm{~m}, 1 \mathrm{H})$, $7.32(\mathrm{~m}, 2 \mathrm{H}), 7.30(\mathrm{~m}, 1 \mathrm{H}), 7.26(\mathrm{~m}, 1 \mathrm{H}), 6.89(\mathrm{~m}, 2 \mathrm{H}), 5.39$ (d, $J=5.6 \mathrm{~Hz}, 1 \mathrm{H}), 4.91$ (t, $J=4.3 \mathrm{~Hz}, 1 \mathrm{H}), 4.82$ (d, $J=11.7$ $\mathrm{Hz}, 1 \mathrm{H}), 4.72(\mathrm{~d}, J=11.7 \mathrm{~Hz}, 1 \mathrm{H}), 4.66$ (dd, $J=7.3,5.6 \mathrm{~Hz}$, $1 \mathrm{H}), 4.02$ (dd, $J=7.3,4.0 \mathrm{~Hz}, 1 \mathrm{H}), 3.80$ (s, OMe), 2.83 (d, $J=$ $4.8 \mathrm{~Hz}, 1 \mathrm{H}), 1.50$ (s, Me), 1.33 (s, Me); ${ }^{13} \mathrm{C}-\mathrm{NMR}(150 \mathrm{MHz}$, $\left.\mathrm{CDCl}_{3}\right): \delta 159.7,155.9,152.0,129.8,129.6,128.9,126.4$, 125.1, 123.3, 120.1, 114.1, 111.7, 110.8, 78.2, 75.8, 73.0, 69.6, 62.9, 55.3, 28.1, 26.3; IR $v_{\max } / \mathrm{cm}^{-1} 2957,2924,2853,1637$, 1080, 1034, 923.

Homobenzyl ether 12 (27 mg, 16\%); $R_{\mathrm{f}}=0.20$ (30\% EtOAc in hexane); $[\alpha]_{\mathrm{D}}-8.2$ (c $0.9, \mathrm{CHCl}_{3}$ ); HRMS (ES) calcd for $\mathrm{C}_{23} \mathrm{H}_{28} \mathrm{NO}_{6}\left(\mathrm{M}+\mathrm{NH}_{4}\right)^{+} 414.1917$ found 414.1928; ${ }^{1} \mathrm{H}-\mathrm{NMR}$ $\left(600 \mathrm{MHz}, \mathrm{CDCl}_{3}\right): \delta 7.69(\mathrm{~d}, J=7.5 \mathrm{~Hz}, 1 \mathrm{H}), 7.52(\mathrm{~d}, J=8.3$ $\mathrm{Hz}, 1 \mathrm{H}), 7.35$ (dt, $J=7.3,1.2 \mathrm{~Hz}, 1 \mathrm{H}), 7.32$ (d, $J=8.6 \mathrm{~Hz}, 2 \mathrm{H}$ ), 7.29 (dt, $J=7.5,1.0 \mathrm{~Hz}, 1 \mathrm{H}), 6.89$ (d, $J=8.6 \mathrm{~Hz}, 2 \mathrm{H}), 5.42$ (d, $J=5.7 \mathrm{~Hz}, 1 \mathrm{H}), 4.84(\mathrm{~d}, J=11.2 \mathrm{~Hz}, 1 \mathrm{H}), 4.74(d, \mathrm{~J}=4.1 \mathrm{~Hz}$, $1 \mathrm{H}), 4.71$ (d, $J=11.2 \mathrm{~Hz}, 1 \mathrm{H}), 4.57$ (dd, $J=7.7,5.8 \mathrm{~Hz}, 1 \mathrm{H}$ ), 4.19 (td, $J=7.5,4.0 \mathrm{~Hz}, 1 \mathrm{H}), 3.81$ (s, OMe), 2.64 (d, $J=7.5$ $\mathrm{Hz}, 1 \mathrm{H}), 1.51$ (s, Me), 1.43 (s, Me); ${ }^{13} \mathrm{C}-\mathrm{NMR}$ (150 MHz, $\left.\mathrm{CDCl}_{3}\right): \delta 159.6,155.9,152.2,129.8,129.4,126.5,125.3$, 123.4, 120.3, 114.0, 113.6, 111.7, 110.8, 77.6, 72.3, 71.5, 70.3,
69.5, 55.3, 28.2, 26.2; IR $v_{\max } / \mathrm{cm}^{-1} 2958,2925,2853,1641$, 1080, 1012, 907.

A small portion of the minor diastereoisomer 10b was separated from the acetal mixture 10a/10b by multiple elution PLC. This sample on similar DIBAL reduction gave exclusively isomer 12.

(3aR,4S,5S,10cR)-4-Methoxy-5-((4-methoxybenzyl)oxy)-2,2dimethyl-3a,4,5,10c-tetrahydrobenzo[b][1,3] dioxolo [4,5e]benzofuran (13). To a solution of alcohol 11 (16 mg, 0.040 $\mathrm{mmol})$ in dry THF (4 mL) was added sodium hydride (5 mg), under an argon atmosphere, followed by the addition of methyl iodide $(12 \mu \mathrm{L})$. The reaction mixture was stirred $(4 \mathrm{~h})$ at room temperature, the solvent removed in vacuo, and the crude product purified by flash column chromatography (10\% EtOAchexane), to afford methyl ether 13 (14.9 mg, 90\%), colorless oil; $R_{\mathrm{f}} 0.24$ (20\% EtOAc in hexane); $[\alpha]_{\mathrm{D}}-95.6$ (c 0.5, $\mathrm{CHCl}_{3}$ ); HRMS (ES) calcd for $\mathrm{C}_{24} \mathrm{H}_{30} \mathrm{NO}_{6}\left(\mathrm{M}+\mathrm{NH}_{4}\right)^{+} 428.2073$ found 428.2052; ${ }^{1} \mathrm{H}-\mathrm{NMR}\left(600 \mathrm{MHz}, \mathrm{CDCl}_{3}\right): \delta 7.68(\mathrm{~d}, J=7.7 \mathrm{~Hz}$, $1 \mathrm{H}), 7.51$ (d, $J=8.2 \mathrm{~Hz}, 1 \mathrm{H}), 7.37$ (d, $J=8.8 \mathrm{~Hz}, 2 \mathrm{H}), 7.34$ (dt, $J=7.3,1.3 \mathrm{~Hz}, 8 \mathrm{H}), 7.29$ (dt, $J=7.61 .0 \mathrm{~Hz}, 9 \mathrm{H}), 6.89$ (d, $J=8.6 \mathrm{~Hz}, 1 \mathrm{H}), 5.43(\mathrm{~d}, J=6.2 \mathrm{~Hz}, 1 \mathrm{H}), 4.81(\mathrm{~d}, J=3.6 \mathrm{~Hz}$, $1 \mathrm{H}), 4.75$ (d, $J=11.7 \mathrm{~Hz}, 1 \mathrm{H}), 4.74$ (dd, $J=8.5,6.2 \mathrm{~Hz}, 1 \mathrm{H})$, 4.68 (d, $J=11.7 \mathrm{~Hz}, 1 \mathrm{H}), 3.80$ (s, OMe), 3.67 (dd, $J=8.5,3.6$ $\mathrm{Hz}, 1 \mathrm{H}$ ), 3.48 (s, OMe), 1.52 (s, Me), 1.49 (s, Me); ${ }^{13} \mathrm{C}-\mathrm{NMR}$ (150 MHz, $\left.\mathrm{CDCl}_{3}\right): \delta 159.4,155.9,152.9,129.9,129.8,126.4$, 125.2, 123.4, 120.4, 113.8, 113.4, 111.7, 110.7, 81.6, 76.1, 71.7, 69.4, 66.9, 58.1, 55.3, 28.2, 25.8; IR $v_{\max } / \mathrm{cm}^{-1} 2956,2924$, 2854, 1514, 1249, 1109, 874.

(1R,2R,3S,4S)-3-Methoxy-4-((4-methoxybenzyl)oxy)-1,2,3,4tetrahydrodibenzo[b,d]furan-1,2-diol (14). A solution of methyl ether 13 (8.0 mg, $0.020 \mathrm{mmol})$ in THF- $\mathrm{H}_{2} \mathrm{O}(9: 1,2 \mathrm{~mL})$ was treated with TFA $(10 \mu \mathrm{L})$. The reaction mixture was stirred $\left(50^{\circ} \mathrm{C}\right)$ overnight, concentrated in vacuo, and the product purified by flash column chromatography (60\% EtOAc in hexane), to yield cis-diol 14 (7.0 mg, 97\%), colorless oil; $R_{\mathrm{f}} 0.25$ (60\% EtOAc-hexane); $[\alpha]_{\mathrm{D}}-139.0$ (c 0.7, $\mathrm{CHCl}_{3}$ ); HRMS (ES) calcd for $\mathrm{C}_{21} \mathrm{H}_{22} \mathrm{O}_{6} \mathrm{Na}(\mathrm{M}+\mathrm{Na})^{+} 393.1314$ found 393.1302; ${ }^{1} \mathrm{H}-\mathrm{NMR}$ $\left(600 \mathrm{MHz}, \mathrm{CDCl}_{3}\right): \delta 7.68(\mathrm{~d}, J=7.7 \mathrm{~Hz}, 1 \mathrm{H}), 7.51$ (d, $J=8.2$ $\mathrm{Hz}, 1 \mathrm{H}), 7.40$ (d, $J=8.6 \mathrm{~Hz}, 2 \mathrm{H}), 7.34$ (dt, $J=7.3,1.3 \mathrm{~Hz}, 1 \mathrm{H}$ ), 7.28 (dt, $J=7.6,1.0 \mathrm{~Hz}, 1 \mathrm{H}), 6.90$ (d, $J=8.6 \mathrm{~Hz}, 2 \mathrm{H}), 5.16$ (d, $J=4.2 \mathrm{~Hz}, 1 \mathrm{H}), 4.84(\mathrm{~d}, J=3.9 \mathrm{~Hz}, 1 \mathrm{H}), 4.80(\mathrm{~d}, J=11.7 \mathrm{~Hz}$, $1 \mathrm{H}), 4.74$ (d, $J=11.7 \mathrm{~Hz}, 1 \mathrm{H}), 4.37$ (dd, $J=10.2,3.9 \mathrm{~Hz}, 1 \mathrm{H})$, 3.81 (s, OMe), 3.78 (dd, $J=10.1,3.9 \mathrm{~Hz}, 1 \mathrm{H}), 3.39$ (s, OMe), 3.22 (br s, $2 \mathrm{H}$ ); ${ }^{13} \mathrm{C}-\mathrm{NMR}\left(150 \mathrm{MHz}, \mathrm{CDCl}_{3}\right.$ ): $\delta 159.5,156.0$, 152.4, 130.2, 129.6, 126.4, 125.2, 123.3, 120.1, 116.0, 113.9, 111.7, 78.1, 71.7, 68.3, 65.9, 62.5, 57.2, 55.3; IR $v_{\max } / \mathrm{cm}^{-1} 3998$, 2955, 2917, 2849, 1576, 1382, 1222, 1033, 751.

(2S,3S,4S)-2-Hydroxy-3-methoxy-4-((4-methoxybenzyl)oxy)-3,4dihydrodibenzo[b,d]furan-1 $(2 \mathrm{H})$-one (15). TEMPO (1 mg) and Oxone (28 $\mathrm{mg}, 0.09 \mathrm{mmol}$ ) were sequentially added to a stirred solution of cis-diol $14(15 \mathrm{mg}, 0.041 \mathrm{mmol})$ and tetrabutylammonium bromide (2 mg) in dry $\mathrm{CH}_{2} \mathrm{Cl}_{2}(4 \mathrm{~mL})$. After stirring the reaction mixture, overnight at room temperature, the volatiles were removed in vacuo, and the residue purified by flash column chromatography (50\% EtOAc in hexane) to afford ketone 15 (12.8 mg, $86 \%)$, a pale-yellow oil; $R_{\mathrm{f}}=0.33$ (50\% EtOAc in hexane); $[\alpha]_{\mathrm{D}}-$ 118.0 (c 1.0, $\mathrm{CHCl}_{3}$ ); HRMS (ES) calcd for $\mathrm{C}_{21} \mathrm{H}_{20} \mathrm{O}_{6} \mathrm{Na}(\mathrm{M}+$ $\mathrm{Na})^{+} 391.1158$ found 391.1155; ${ }^{1} \mathrm{H}-\mathrm{NMR}\left(600 \mathrm{MHz}, \mathrm{CDCl}_{3}\right): \delta$ $8.08(\mathrm{dm}, 1 \mathrm{H}), 7.58(\mathrm{~m}, 1 \mathrm{H}), 7.44$ (td, $J=7.3,1.5 \mathrm{~Hz}, 1 \mathrm{H}), 7.42-$ 7.38 (m, 8H, 3H), 6.91 (d, $J=8.7 \mathrm{~Hz}, 2 \mathrm{H}), 5.04(\mathrm{~d}, J=3.8 \mathrm{~Hz}, 1 \mathrm{H})$, 4.88 (dd, $J=9.9,1.0 \mathrm{~Hz}, 1 \mathrm{H}), 4.83(\mathrm{~d}, J=11.7 \mathrm{~Hz}, 1 \mathrm{H}), 4.80$ (d, $J$ $=11.7 \mathrm{~Hz}, 1 \mathrm{H}), 3.81$ (s, OMe), $3.72(\mathrm{dd}, J=9.9,3.7 \mathrm{~Hz}, 1 \mathrm{H}), 3.59$ (d, $J=1.2 \mathrm{~Hz}, 1 \mathrm{H}), 3.54$ (3H, s, OMe); ${ }^{13} \mathrm{C}-\mathrm{NMR}(150 \mathrm{MHz}$, 
$\left.\mathrm{CDCl}_{3}\right): \delta 191.5,165.9,159.4,156.2,130.1$ (2), 129.1, 126.7, 125.3, 122.5 (2), 116.1, 114.0 (2), 111.9, 83.1, 73.6, 72.5, 67.4, 58.2, 55.4; IR $v_{\max } / \mathrm{cm}^{-1} 3844,3681,2948,2880,1652,1410$, 1128, 1044, 852.

(2S,3R,4S)-2,3-Dimethoxy-4-((4-methoxybenzyl)oxy)-3,4-dihydrodibenzo[b,d]furan-1(2H)-one (16). Following the procedure described for the synthesis of methyl ether $\mathbf{9}$, a mixture of ketone 15 (9.2 mg, $0.025 \mathrm{mmol}), \mathrm{Ag}_{2} \mathrm{O}$ (8.0 mg) and $\mathrm{MeI}$ (10 $\mu \mathrm{L})$ in dry THF ( $2 \mathrm{~mL})$ was heated in a sealed tube under argon atmosphere. The crude product obtained was purified by flash column chromatography (20\% EtOAc in hexane) to give dimethoxy ketone 16 (7.3 mg, 76\%), colorless oil; $R_{\mathrm{f}}=0.21$ (30\% EtOAc in hexane); $[\alpha]_{\mathrm{D}}-139.0\left(c 0.7, \mathrm{CHCl}_{3}\right)$; HRMS (ES) calcd for $\mathrm{C}_{22} \mathrm{H}_{23} \mathrm{O}_{6}(\mathrm{M}+\mathrm{H})^{+} 383.1495$ found 383.1471; ${ }^{1} \mathrm{H}-\mathrm{NMR}(600$ $\mathrm{MHz}, \mathrm{CDCl}_{3}$ ): $\delta 8.09$ (dm, $\left.J=7.7 \mathrm{~Hz}, 1 \mathrm{H}\right), 7.55(\mathrm{~m}, 1 \mathrm{H}), 7.43-$ 7.35 (m, 4H), 6.92 (d, $J=8.7 \mathrm{~Hz}, 2 \mathrm{H}), 5.05$ (d, $J=3.8 \mathrm{~Hz}, 1 \mathrm{H}$ ), 4.88 (d, $J=11.8 \mathrm{~Hz}, 1 \mathrm{H}), 4.80$ (d, $J=11.8 \mathrm{~Hz}, 1 \mathrm{H}), 4.31$ (d, $J$ $=8.5 \mathrm{~Hz}, 1 \mathrm{H}$ ), 3.98 (dd, $J=8.4,3.7 \mathrm{~Hz}, 1 \mathrm{H}), 3.82$ (s, OMe), 3.70 (s, OMe), 3.52 (s, OMe); ${ }^{13} \mathrm{C}-\mathrm{NMR}\left(150 \mathrm{MHz}, \mathrm{CDCl}_{3}\right): \delta$ 190.9, 165.3, 159.6, 155.9, 130.0, 129.3, 126.2, 125.0, 123.1, 122.5, 116.4, 114.0, 111.7, 82.5, 81.9, 72.6, 68.7, 60.5, 59.0, 55.4; IR $v_{\max } / \mathrm{cm}^{-1} 2947,2880,1739,1684,1484,1281,1041$.

(2S,3R,4S)-4-hydroxy-2,3-dimethoxy-3,4-dihydrodi-

benzo[b,d]furan-1(2H)-one (Ribisin B). 1,7

Following the procedure described for the last step in the synthesis of ribisin A, a solution of dimethoxy ketone 16 (7.6 mg, $0.020 \mathrm{mmol})$ in $\mathrm{CH}_{2} \mathrm{Cl}_{2}$ and $\mathrm{H}_{2} \mathrm{O}(4: 1,2 \mathrm{~mL})$ was reacted with DDQ (5 mg). Purification of the crude product by flash column chromatography (25\% EtOAc in hexane) furnished ribisin B (4.0 mg, 77\%), a colorless oil; $R_{\mathrm{f}}=0.25$ (30\% EtOAc in hexane); $[\alpha]_{D}-25.8$ ( $c$ 0.4, $\mathrm{CHCl}_{3}$ ); HRMS (ES) calcd for $\mathrm{C}_{14} \mathrm{H}_{15} \mathrm{O}_{5}$ $(\mathrm{M}+\mathrm{H})^{+} 263.0919$ found 263.0912; ${ }^{1} \mathrm{H}-\mathrm{NMR}(600 \mathrm{MHz}$, $\left.\mathrm{CDCl}_{3}\right): \delta 8.08(\mathrm{dm}, J=7.6 \mathrm{~Hz}, 1 \mathrm{H}), 7.56(\mathrm{dm}, J=7.7 \mathrm{~Hz}, 1 \mathrm{H})$, 7.41-7.35 (m, 2H), 5.30 (dd, $J=7.1,4.2 \mathrm{~Hz}, 1 \mathrm{H}$ ), 4.15 (d, $J=$ $6.7 \mathrm{~Hz}, 1 \mathrm{H}$ ), 4.01 (dd, $J=6.7,4.2 \mathrm{~Hz}, 1 \mathrm{H}$ ), 3.62 (s, OMe), 3.61 (s, OMe), 3.05 (d, $J=7.1 \mathrm{~Hz}, 1 \mathrm{H}) ;{ }^{13} \mathrm{C}-\mathrm{NMR}(150 \mathrm{MHz}$, $\left.\mathrm{CDCl}_{3}\right): \delta 190.2,165.2,155.8,126.1,124.9,123.1,122.3$, 115.3, 111.8, 81.9, 81.7, 63.8, 59.8, 59.5 . 


\section{REFERENCES}

1. Liu, Y. H.; Kubo, M.; Fukuyama, Y., Nerve Growth Factor-Potentiating Benzofuran Derivatives from the Medicinal Fungus Phellinus ribis. J. Nat. Prod. 2012, 75, 2152-7.

2. Liu, Y. H.; Wang, F. S., Structural characterization of an active polysaccharide from Phellinus ribis. Carbohydr. Polym. 2007, 70, 386-92.

3. Lee, I. K.; Lee, J. H.; Yun, B. S., Polychlorinated compounds with PPARgamma agonistic effect from the medicinal fungus Phellinus ribis. Bioorg. Med. Chem. Lett. 2008, 18, 4566-8.

4. Kubo, M.; Liu, Y. H.; Ishida, M.; Harada, K.; Fukuyama, Y., A New Spiroindene Pigment from the Medicinal Fungus Phellinus ribis. Chem. Pharm. Bull. 2014, 62, 122-4.

5. Zhang, C. L.; Liu, J.; Du, Y. G., Total synthesis of ribisin A. Tetrahedron Lett. 2014, 55, 959-61.

6. Lan, P.; Banwell, M. G.; Ward, J. S.; Willis, A. C., Chemoenzymatic Total Synthesis and Reassignment of the Absolute Configuration of Ribisin C. Org. Lett. 2014, 16, 228-31.

7. Lan, P.; Banwell, M. G.; Willis, A. C., Chemoenzymatic Total Syntheses of Ribisins A, B, and D, Polyoxygenated Benzofuran Derivatives Displaying NGFPotentiating Properties. J. Org. Chem. 2014, 79, 2829-42.

8. Boyd, D. R.; Sharma, N. D.; Harrison, J. S.; Malone, J. F.; McRoberts, W. C.; Hamilton, J. T. G.; Harper, D. B., Enzyme-catalysed synthesis and reactions of benzene oxide/oxepine derivatives of methyl benzoates. Org. Biomol. Chem. 2008, 6, 1251-9.

9. Min, K. L.; Kim, Y. H.; Kim, Y. W.; Jung, H. S.; Hah, Y. C., Characterization of a novel laccase produced by the wood-rotting fungus Phellinus ribis. Arch. Biochem. Biophys. 2001, 392, 279-86.

10. Tang, F.; Lan, P.; Bolte, B.; Banwell, M. G.; Ward, J. S.; Willis, A. C., Total Synthesis of (+)-Viridianol, a Marine-Derived Sesquiterpene Embodying the Decahydrocyclobuta d indene Framework. J. Org. Chem. 2018, 83, 14049-56.

11. Dlugosch, M.; Banwell, M. G., Synthesis of a Highly Functionalised and Homochiral 2Iodocyclohexenone Related to the C-Ring of the Polycyclic, Indole Alkaloids Aspidophytine and Haplophytine. Aust. J. Chem. 2018, 71, 573-9.

12. Dlugosch, M.; Ma, X. H.; Yang, S. X.; Banwell, M. G.; Ma, C. X.; Ward, J. S.;
Carr, P., Syntheses of Structurally and Stereochemically Varied Forms of $\mathrm{C}_{7} \mathrm{~N}$ Aminocyclitol Derivatives from Enzymatically Derived and Homochiral cis1,2-Dihydrocatechols. Org. Lett. 2018, 20 , 7225-8.

13. Baidilov, D.; Rycek, L.; Trant, J. F.; Froese, J.; Murphy, B.; Hudlicky, T., Chemoenzymatic Synthesis of Advanced Intermediates for Formal Total Syntheses of Tetrodotoxin. Angew. Chem., Int. Ed. 2018, 57, 10994-8.

14. Borra, S.; Kumar, M.; McNulty, J.; Baidilov, D.; Hudlicky, T., Chemoenzymatic Synthesis of the Antifungal Compound (-)-Pestynol by a Convergent, Sonogashira Construction of the Central Yne-Diene. Eur. J. Org. Chem. 2019, 77-9.

15. Borra, S.; Lapinskaite, R.; Kempthorne, C.; Liscombe, D.; McNulty, J.; Hudlicky, T., Isolation, Synthesis, and Semisynthesis of Amaryllidaceae Constituents from Narcissus and Galanthus sp.: De Novo Total Synthesis of 2-epi-Narciclasine. J. Nat. Prod. 2018, 81, 1451-9.

16. Endoma-Arias, M. A. A.; Makarova, M.; Dela Paz, H. E.; Hudlicky, T., Chemoenzymatic Total Synthesis of (+)Oxycodone from Phenethyl Acetate. Synthesis-Stuttgart 2019, 51, 225-32.

17. Hudlicky, T., Benefits of Unconventional Methods in the Total Synthesis of Natural Products. Acs Omega 2018, 3, 17326-40.

18. Lewis, S. E., Applications of biocatalytic arene ipso, ortho cis-dihydroxylation in synthesis. Chem. Commun. 2014, 50, 282130.

19. Lewis, S. E., Asymmetric Dearomatisation Under Enzymatic Conditions. In Asymmetric Dearomatisation Reactions, You, S. L., Ed. Wiley-VCH: Weinheim, 2016; pp 279-346.

20. Boyd, D. R.; Sharma, N. D.; Carroll, J. G.; Loke, P. L.; O'Dowd, C. R.; Allen, C. C. R., Biphenyl dioxygenase-catalysed cisdihydroxylation of tricyclic azaarenes: chemoenzymatic synthesis of arene oxide metabolites and furoquinoline alkaloids. RSC Adv. 2013, 3, 10944-55.

21. Resnick, S. M.; Gibson, D. T., Regio- and stereospecific oxidation of fluorene, dibenzofuran, and dibenzothiophene by naphthalene dioxygenase from Pseudomonas sp strain NCIB 9816-4. Appl. Environ. Microbiol. 1996, 62, 4073-80.

22. Cerniglia, C. E.; Morgan, J. C.; Gibson, D. T., Bacterial and Fungal Oxidation of Dibenzofuran. Biochem. J. 1979, 180, 17585.

23. Bianchi, D.; Bosetti, A.; Cidaria, D.; Bernardi, A.; Gagliardi, I.; Damico, P., 
Oxidation of polycyclic aromatic heterocycles by Pseudomonas fluorescens TTC1. Appl. Microbiol. Biotechnol. 1997, 47, 596-9.

24. Boyd, D. R.; Sharma, N. D.; Malone, J. F.; McIntyre, P. B. A.; Stevenson, P. J.; Allen, C. C. R.; Kwit, M.; Gawronski, J., Structure, stereochemistry and synthesis of enantiopure cyclohexenone $\mathrm{cis}$-diol bacterial metabolites derived from phenols. Org.

Biomol. Chem. 2012, 10, 6217-29.

25. Boyd, D. R.; Sharma, N. D.; Malone, J. F.; McIntyre, P. B. A.; McRoberts, C.; Floyd, S.; Allen, C. C. R.; Gohil, A.; Coles, S. J.; Horton, P. N.; Stevenson, P. J., Toluene Dioxygenase-Catalyzed Synthesis and Reactions of $c i s$-Diol Metabolites Derived from 2-and 3-Methoxyphenols. J. Org. Chem. 2015, 80, 3429-39.

26. Boyd, D. R.; Sharma, N. D.; McIntyre, P. B. A.; Stevenson, P. J.; McRoberts, W. C.; Gohil, A.; Hoering, P.; Allen, C. C. R., Enzyme-Catalysed Synthesis of Cyclohex-2en-1-one $c i s$-Diols from Substituted Phenols, Anilines and Derived 4Hydroxycyclohex-2-en-1-ones. Adv. Synth. Catal. 2017, 359, 4002-14.

27. Boyd, D. R.; Sharma, N. D.; Brannigan, I. N.; McGivern, C. J.; Nockemann, P.; Stevenson, P. J.; McRoberts, C.; Hoering, P.; Allen, C. C. R., Cis-Dihydroxylation of Tricyclic Arenes and Heteroarenes Catalyzed by Toluene Dioxygenase: A Molecular Docking Study and Experimental Validation. Adv. Synth. Catal. 2019, 361, 2526-37.

28. Vanrheenen, V.; Kelly, R. C.; Cha, D. Y., Improved Catalytic $\mathrm{OsO}_{4}$ Oxidation of

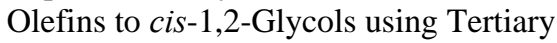
Amine Oxides as Oxidant. Tetrahedron Lett. 1976, 1973-6.

29. Bolm, C.; Magnus, A. S.; Hildebrand, J. P., Catalytic synthesis of aldehydes and ketones under mild conditions using TEMPO/Oxone. Organic Letters 2000, 2 , 1173-5.

30. Hudlicky, T.; Fan, R. L.; Tsunoda, T.; Luna, H.; Andersen, C.; Price, J. D., Biocatalysis as a Rational Approach to Enantiodivergent Synthesis of Highly Oxygenated Compounds - (+)-Pinitol and (-)-Pinitol and Other Cyclitols. Isr. J. Chem. 1991, 31, 22938.

31. Heravi, M. M.; Zadsirjan, V.; Hamidi, H.; Amiri, P. H. T., Total synthesis of natural products containing benzofuran rings. RSC Adv. 2017, 7, 24470-521.

32. Oliveira, A.; Oliveira-Campos, A. M. F.; Raposo, M. M. M.; Griffiths, J.; Machado, A. E. H., Fries rearrangement of dibenzofuran-2-yl ethanoate under photochemical and Lewis-acid-catalysed conditions. Tetrahedron 2004, 60, 6145-54. 